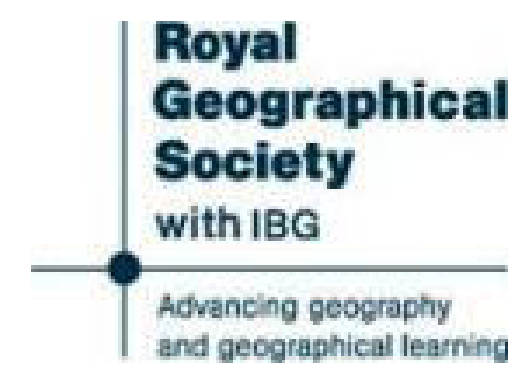

\title{
Botanical Geography
}

Ecology of Plants. An Introduction to the Study of Plant-Communities by Eug. Warming Review by: G. F. S. E.

The Geographical Journal, Vol. 34, No. 4 (Oct., 1909), pp. 448-450

Published by: The Royal Geographical Society (with the Institute of British Geographers)

Stable URL: http://www.jstor.org/stable/1777204

Accessed: 07/12/2014 17:49

Your use of the JSTOR archive indicates your acceptance of the Terms \& Conditions of Use, available at

http://www.jstor.org/page/info/about/policies/terms.jsp

JSTOR is a not-for-profit service that helps scholars, researchers, and students discover, use, and build upon a wide range of content in a trusted digital archive. We use information technology and tools to increase productivity and facilitate new forms of scholarship. For more information about JSTOR, please contact support@jstor.org. 
fractures, characterized also by subsidence and the formation of lakes, lies to the north-west of the vertex and separates it from the Gobi Altai, another region of ancient rocks which has exhibited great stability. A secondary or younger vertex lies in the Altai mountains. Far away to the south are the great rigid masses of peninsular India and Australia. Between these the whole of Asia is traversed by crowded folds, describing great curves, sometimes uniting in a syntaxis and suffering numerous deflections where one system encounters another or is turned aside by rigid districts like the Ordos or the "Sinian mole" which lies to the north-east of the Kuen-Lun mountains.

The analysis of the tectonics of Asia which Prof. Suess presents in this volume is marked by profound scholarship and almost superhuman breadth of view. The work is a great classic of geological research, and though, as its author points out, many of the conclusions arrived at are merely provisional, there is no doubt that it will keep its place in the literature of geology. It is a very difficult book to read, but there are portions of it, like the description of the vertex, the contrast between the fresh-water and saline deposits of Central Asia, and the two kinds of movements which have affected the eastern Alps, which are as readable as they are brilliant.

Miss Sollas's translation maintains its high level of excellence, and is in every way worthy of the book. It has much of the fluency and eloquence of the original, and avoids diffuseness as well as obscurity. Prof. Sollas has acted as general editor, and has been assisted by a number of eminent British geologists, but the original German edition has been followed as closely as possible. This is, no doubt, wise under the eircumstances, though it has distinct inconveniences. Thus the illustrations have their topographical names in German, but in the text the English forms are mostly used. We note, also, that in the map the explanation of the colour scheme, omitted in the German edition, is also omitted in the English one, though it has been given by the French translators.

J. S. F.

\section{Botanical Geography.}

' Ecology of Plants. An Introduction to the Study of Plant-Conımunities.' By Eug. Warming, assisted by Martin Vahl. Prepared for publication in English by Percy Groom and Isaac Bayley Balfour. Oxford: Clarendon Press. 1909. Pp. i.-xi. and 1-422. Price 88. 6d. net.

That interesting development of geographical botany which is clumsily described as œeology depends upon a classical work by Prof. Warming, which was translated into German in 1896. Schimper's ' Plant Geography ' appeared in 1898 (in English in 1903) ; Prof. Clements, in America, published, not a translation, but an original work also in 1903, but English readers have had to wait some thirteen years for any adequate account of Warming's classical researches.

The book under review is, of course, much larger and more elaborate than the original; the author has included all the more important recent observations, and this volume must surely rank as the best modern textbook of a very difficult subject. The first three sections are concerned with the various climatic factors, light, heat, and atmospheric humidity. The chapters dealing with the aëration, depths of water in, and characters of soils are very complete, and these, as well as others which explain the effects of a vegetable covering on soil, of man's interference with vegetation, and of the influence of one plant community upon another, are not only clear, concise, and original, but of the first importance to practical agriculturists, foresters, and geographers.

The major part of the book is, of course, descriptive. Every formation and association in each of the thirteen classes is explained in detail, along with the 
special adaptations to its own peculiar climate and soil, which naturally involves a description, in brief, of every type of vegetation on the whole Earth's surface. In the concluding section, Prof. Warming deals with the struggle for existence amongst the various plant communities, with the formation of new land by plants, and with the succession or change of one type of vegetation into another. All these chapters are exceedingly interesting, and especially the last, on the origin of species, which is a valuable contribution to the theory of evolution.

The most difficult and most important part in the study of plant-communities is to distinguish and classify the particular types. These classes are characterized as follows:-

(a) The soil is very wet. 1. Water plants and 2. Marsh plants.

(b) Soil Physiologically dry, which means that though water may be present even in abundance, it is not available for plant life. 3. Formations of very cold but not peaty soil (polar and high alpine). 4. Sour (acid) soil (tundras, peat-moss, moorlands, and arctic bushlands). 5. Salt plants (Zostera, saltwort, and mangrove formations).

(c) Soil physically dry and of more influence than climate on the life of plants. 6. Rock and gravel plants. 7. Sand-dunes and shingle. 8. "Formations on waste-land."

(d) Climate very dry, as in : 9. Desert and steppes. 10. Tropical savannahs. 11. Hard-leaved bush or forest, such as the Mediterranean maqui.

(e) Soil physically or physiologically dry (at least, that is how we understand it, for there seems to be an unfortunate misprint here), which includes only 12. Coniferous formations.

(f) Soil and climate of a moderately humid character, which contains arctic and alpine mat herbage and mat grasslands, meadows, pastures on cultivated soil, as well as evergreen and deciduous forests both temperate and tropical.

This classification seems to be a revised form of that originally adopted by Warming, and differs entirely from Schimper's method, which depends on climate.

At first sight this new classification seems both ingenious and particularly definite and clear, but the practical application of it in the field may be a little difficult.

It is not generally realized that this science of plant-communities is of great practical importance and not merely a botanical diversion. An expert should be able, in a new country, to judge from the character of the natural flora exactly what the land is capable of producing, or, at any rate, what are the most promising crops for experiment. But if a traveller were to attempt to classify the vegetation, say, in Australia or in Central Africa by means of this handbook alone, it is possible that he might find difficulties. These difficulties are not insuperable; there is nothing essentially mysterious in the most interesting science of plantcommunities, nor is there anything in this volume which is unintelligible, but unfortunately there is an alarming display of formidable technical terms.

It will be most unfortunate if those who are likely to make the best use of this volume should be daunted by the clumsy name given to its subject, by the oxylophytes, chersophytes, etc., which dominate almost every page. Beyond the pleasure which some people seen to enjoy from writing helophyte for marsh plant and heliophobous for shade-loving, it is difficult to see why this unnecessary terminology should have been introduced. It will be a thousand pities if this valuable book should miss its full effect merely on account of its alarming appearance. It is in reality quite clear and easily read.

There are, of course, many points in which botanists would not immediately concur except on the high authority of the author. Must one believe, for instance, 
that the soil in all coniferous forests is either physically or physiologically dry ? There is an indefiniteness in the term "formation of waste land." Our common bracken occurs in this class, but in Scotland bracken overgrows many quite different formations. For instance, it will cover permanent pasture, dry heather moors, clearings in pine forests or in deciduous woodlands. So that there are many different formations in which bracken may become dominant.

Some botanists may have a certain feeling of regret that the author has not attempted to use the principle of succession for his classification. In one short sentence he describes how a marsh may change into a "low" peat-moss, which may become in time a "high moor" upon which a heather-moor may develop, and which may again be occupied by a Scotch pine forest, or in time by deciduous woods. This masterly description explains at once the greater number of the most important plant-formations in Northern Europe. If Prof. Warming could have utilized similar successions of development to explain other formations and associations, it would seem probable that most of the difficulties in its practical application would disappear.

But this work is one which should be indispensable to every British traiveller, and perhaps may result in the British Empire being at last botanically surveyed on thoroughly modern methods. It is hoped that it is correct to assume that the book is entirely the work of Prof. Warming. The two distinguished botanists who have "prepared it for publication in English" would no doubt have marked their own contributions if they had collaborated in its production.

The book contains neither illustrations nor maps, but there is an excellent bibliography and a very full index.

\section{G. F. S. E.}

\section{Hydrographic SuRveying.}

'Hydrographical Surveying.' By the late Rear-Admiral Sir William Wharton. New edition, revised and enlarged by Rear-Admiral Mostyn Field. London: Murray. 1909. 218. net.

Originally published in 1882 , this work has since been considered the standard work on the subject. A second edition was issued in 1898, to bring it up to date, since when the lamented death of the author has occurred. A further edition being now called for, this has been very ably and appropriately prepared by the author's successor as hydrographer, who, avoiding as far as possible any alteration in the text, has added many new features, including descriptions of useful expedients devised by present-day surveyors.

The increased size and draught of modern vessels more than ever necessitates the greatest attention to very close sounding in order to detect all irregularities of the latter, and ensure that no hidden dangers exist. Much additional useful information is given on this important point. In connection with searching for vigias or banks in deep water, the practical effect of a better knowledge of the nature of the slope of the bottom at different depths is also dwelt on. In an extended survey, differences will always occur between resulting positions obtained by triangulation and by astronomical observations; a practical method of satisfactorily co-ordinating them is described. Irregular methods of triangulation are illustrated by a large number of interesting practical examples, which are all the more valuable as being actual cases that have occurred in practice, and which show the value of the exercise of mathematical ingenuity in overcoming difficulties and so obtaining successful results in cases when otherwise a regular triangulation might be altogether impossible, or only to be obtained by the sacrifice and practical waste of much valuable time and labour. Many of the examples show the very great use 